\title{
Foreign Aid and Child Mortality Rate in Nigeria
}

\author{
Funmilola Bukola Adebanji ${ }^{1}$, Philip Ifeakachukwu Nwosa ${ }^{2}$, \\ Olusoji Oluwasegun Ojo ${ }^{3}$, Olamide Jacquilyne Alake ${ }^{4}$ \\ ${ }^{*}$ Corresponding author
}

\begin{abstract}
Several factors have attributed to the high child mortality rate, including poverty, age of women at birth, and length of the interval between births. Besides, the lack of financial resources in developing countries has been a challenge in addressing the prevalent high child mortality rate. Thus, this study seeks to examine the relationship between foreign aid and infant mortality in Nigeria from 1981 to 2018. Employing AutoRegressive Distributed Lag (ARDL) technique, the study observed that foreign aid, government expenditure on health, real GDP, and carbon dioxide emission negatively impacted child mortality. Hence, the study concludes that foreign aid reduces child mortality in Nigeria. The study recommends that the government ensure that all foreign aid and grants use immediately to reduce child mortality by building the necessary infrastructure and making it readily available.
\end{abstract}

Keywords: foreign aid, child mortality, auto-regressive distributed lag

\begin{abstract}
Abstrak
Beberapa faktor telah dikaitkan dengan tingginya angka kematian anak yang meliputi kemiskinan, usia wanita saat lahir dan panjang interval antara kelahiran. Selain itu, kurangnya sumber daya keuangan di negara-negara berkembang telah menjadi tantangan dalam mengatasi masalah tingginya angka kematian anak. Dengan demikian, penelitian ini berupaya untuk menguji hubungan antara bantuan luar negeri dan kematian bayi di Nigeria selama periode 1981 hingga 2018. Menggunakan teknik Auto-Regressive Distributed Lag (ARDL), penelitian ini mengamati bahwa bantuan asing, pengeluaran pemerintah untuk kesehatan, PDB riil dan emisi karbon dioksida berdampak negatif pada tingkat kematian anak. Oleh karena itu, penelitian ini menyimpulkan bahwa bantuan asing mengurangi angka kematian anak di Nigeria. Studi ini merekomendasikan bahwa pemerintah harus memastikan bahwa semua bantuan dan hibah luar negeri digunakan segera untuk mengurangi angka kematian anak dengan membangun infrastruktur yang diperlukan dan membuatnya tersedia.
\end{abstract}

Kata Kunci: bantuan luar negeri, kematian anak, auto-regressive distributed lag

JEL Classification: F35, I19

\section{How to Cite:}

Adebanji, F. B., Nwosa, P. I., Ojo, O. O., \& Alake, O. J. (2020). Foreign Aid and Child Mortality Rate in Nigeria. Signifikan: Jurnal Ilmu Ekonomi, 9(2), 187-194. doi: http://doi.org/10.15408/sjie.v9i2.14960. 


\section{Introduction}

Reduction in child mortality in developing countries reflects in several of the United Nations' developmental agendas -the Millennium and Sustainable Development Goals. Several factors have attributed to the high child/infant mortality rate, which includes poverty, age of women at birth, gender inequality, and length of the interval between births (Klugman et al., 2019; Alan Guttmecher Institute, 1995). Besides, the lack of financial resources in developing countries has been a challenge in addressing the issue of the prevailing high mortality rate. Consequently, developing countries have relied on foreign aid in solving health problems. Nevertheless, debates on the relationship between foreign aid and health outcomes have been inconclusive in the literature (Kotsadam et al., 2018; Thomson et al., 2017; Yogo \& Mallaye, 2015; Pandolfelli et al., 2014; Mishra \& Newhouse (2009).

Proponents of foreign aid (such as International Health Organizations) have advocated the need for more foreign aid to developing to reduce the negative health outcomes. To this end, several donor countries have pledged to increase funding to the countries with the lowest health indicators to reduce maternal mortality levels in those countries (Proulx et al., 2017). However, opponents of foreign aid maintained that aid has been ineffective in improving health outcomes. Aid critics stressed that, despite the increase in foreign aid to developing counties over the years, health outcomes had not experienced any significant decline. Instead, the results have always been catastrophic, leaving more than a billion people living in abject poverty (Easterly, 2006; Moyo, 2009; Winters, 2010). For instance, about \$11.6b was invested in maternal health in low and medium-income countries (LMICs) between 1990 and 2017, yet maternal mortality rate is still prevalent in these countries (Institute for Health Metrics and Evaluation [IHME], 2018). This condition further buttresses by the inability of the achieve the 5th Goal from the Millennium Development Goal. Consequently, the Sustainable Development Goals (SDG 3) set a target of reducing Infant/maternal rate to 70 per 100,000 live births by 2030 .

Despite the efforts of foreign organizations, agencies, and governments to support the health sector in Sub-Saharan Africa, there has been an increasing rate of child mortality. For instance, in 2018, USAID provided about $\$ 89$ million to support Nigeria in various sectors, with more than half allocated to the health sector. Despite the relevance of such foreign aid, the rate of infant/child mortality rate is still on the rise, thereby creating doubt on the potential impact of foreign aid on infant/child mortality rate in Nigeria. Hence it is crucial to assess aid's efficacy in reducing infant mortality. More so, little or no studies exist on this issue in Nigeria. Previous studies only examined the link between foreign aid and other human development (Joseph et al., 2017; Nasim et al., 2009; Staicu \& Barbulescu, 2017; Johnson \& Peter, 2009; Masud \& Yontcheva, 2005).

In comparison, Maruta et al. (2020) focused on the impact of foreign aids and institutional quality on economic growth. Clements (2020) focuses on improving learning and accountability in foreign aid. Kaya \& Kaya (2020) examine the link between foreign aid institutional quality and government fiscal behavior in emerging countries. Most indigenous studies examined the link between foreign aid and economic growth in Nigeria (Olabode \& Salam, 2018; Bashir, 2013; Fasanya \& Onakoya, 2012; Bakare, 2011). The few studies on the link between foreign aid and maternal mortality in Nigeria are either cross-sectional (Dingle 
et al., 2020) or micro-level study (Kotsadam et al., 2018). A macro-time series countryspecific study on Nigeria is lacking. Thus, this is the research gap this study seeks to fill in the literature by examining the relationship between foreign aid and child mortality in Nigeria.

Examining this issue is important because health is indispensable to improve human productivity; hence the outcome of this study would reveal the extent to which foreign aid has contributed to infant mortality rate and offer solutions to improving the health sector. Besides the above, there has been continuous increased significant attention of international institutions to the issues of infant mortality; however, the relative absence of empirical evidence on the relationship between foreign aid and infant mortality is surprising. Thus, the purpose of this study is to close the literature gap by examining the impact of foreign aid on the child mortality rate in Nigeria. In this light, the study contributes to the existing literature by showing that foreign aids contribute to reducing the child mortality rate in Nigeria.

\section{Method}

To examine the relationship between infant mortality rate and foreign aid in Nigeria, this study adopts a modified model by Yousuf (2012) on the link between health aid and infant mortality. The modified model is:

$$
\mathrm{CMR}=\mathrm{f}(\text { FAID, GHE, CO2, EG, ) }
$$

The econometric model for this study is shown as:

$$
\mathrm{CMR}=\beta_{\mathrm{o}}+\beta_{1} \mathrm{FAID}+\beta_{2} \mathrm{GEH}+\beta_{3} \mathrm{CO} 2+\beta_{4} \mathrm{EG}+\mu
$$

Where $\beta_{0}$ is constant, $\beta_{1}, \beta_{2}, \beta_{3}$ and $\beta_{4}$ are coefficient of the independent variables and is the error term. Theoretically, it is expected that, $\beta_{1}<0, \beta_{2}<0, \beta_{3}>0$ and $\beta_{4}<0$. Data of child mortality rate (CMR) refers to the probability of children dying between birth and age five expressed per 1000 live birth. Foreign aid (FAID) is government and institutional assistance designed to promote the recipient country's growth and development (OECD, 2019). The federal government budgetary allocation measures government expenditure on health to the health sector. Real gross domestic product is using to measure economic growth. Data on child mortality rate, foreign aid and carbon dioxide emission were sourced from World Bank Database, while data on government expenditure on health $(\mathrm{GEH})$ and real gross domestic product (EG) source from the Central Bank of Nigeria Statistical Bulletin, 2018 edition. The model is estimated using Auto-regressive Distributed Lag (ARDL) estimation techniques.

\section{Results and Discussion}

The descriptive statistics of the variables presents in Table 1 . The mean values of child mortality rate (CMR), foreign aid (FAID), government health expenditure (GHE), economic growth (EG), and carbon dioxide emission (CO) are 182.8576, 1.07E+09, 38.95152, 28459.07 and 0.602856 respectively. The skewness statistic shows that child mortality rate (CMR) and carbon dioxide emission (CO) are negatively skew, while foreign aid (FAID), government health expenditure (GEH) and economic growth (RGDP) positively skew. The kurtosis statistics show that foreign aid (FAID) and government health expenditure (GHE) is leptokurtic, suggesting that the distribution of the variable is peaked relative to the normal distribution. At the same 
time, child mortality rate (CMR), economic growth (EG), and Carbon Dioxide Emission (CO) are platykurtic, suggesting that the distribution is flat relative to normal distribution. Finally, the Jarque-Bera statistic rejected the null hypothesis of the normal distribution for child mortality rate (CMR), economic growth (EG), and carbon dioxide emission (CO). At the same time, it accepted the null hypothesis of the normal distribution for foreign aid (FAID) and government health expenditure (GHE) at five percent level of significance.

Table 1. Descriptive Statistics

\begin{tabular}{lccccc}
\hline \multicolumn{1}{c}{ Variables } & CMMR & FAID & GHE & EG & CO \\
\hline Mean & 182.8576 & $1.07 \mathrm{E}+09$ & 38.9515 & 28459.07 & 0.6029 \\
Std. Dev. & 32.8613 & $2.23 \mathrm{E}+09$ & 61.6506 & 15023.71 & 0.1806 \\
Skewness & -0.7898 & 3.5750 & 1.8498 & 1.0273 & -0.1219 \\
Kurtosis & 2.1108 & 16.0621 & 5.5554 & 2.7367 & 1.6964 \\
Jarque-Bera & 4.5184 & 304.8947 & 27.7983 & 5.9003 & 2.4182 \\
Probability & 0.1044 & 0.0000 & 0.0000 & 0.0523 & 0.2985 \\
Observations & 33 & 33 & 33 & 33 & 33 \\
\hline
\end{tabular}

Source: Data processing

The unit root test presented in this study follows the Phillips-Perron procedure. The test carries out to examine the stationary nature of each of the variables used in the models of this research study in order to avoid the consequence of having a spurious regression result arising from conducting ordinary least squares method with non-stationary series. Table 2 shows that child mortality rate (CMR), government expenditure on health (GHE), carbon dioxide emission (CO) and economic growth (EG) is stationary at the first difference, implying that the variables are I(1) series. At the same time, foreign aid (FAID) is stationary at a level indicating that the variable is $\mathrm{I}(0)$ series.

Table 2. Phillips-Perron Unit Root Test

\begin{tabular}{cccc}
\hline VARIABLES & LEVEL & 1 $^{\text {ST }}$ DIFFERENCE & STATUS/REMARKS \\
\hline CMR & 1.5042 & $-1.0716^{*}$ & $\mathrm{I}(1)$ \\
LFAID & $-2.9561^{* *}$ & - & $\mathrm{I}(0)$ \\
LGHE & -0.8512 & $-18.4447^{*}$ & $\mathrm{I}(1)$ \\
CO & -2.1170 & $-6.5186^{*}$ & $\mathrm{I}(1)$ \\
LEG & 0.6846 & $-3.2426^{*}$ & $\mathrm{I}(1)$ \\
\hline
\end{tabular}

Sources: Data processing

Note: ${ }^{*}$ and ${ }^{* *}$ indicates $1 \%$ and $5 \%$ respectively.

Table 3 presents the co-integration test for the variables in the model to verify the existence of a long-run relationship using the ARDL bound co-integration test. Unlike the Johansen co-integration technique, which requires that the variables must integrate of order one, the ARDL co-integration approach is applicable irrespective of whether the variables 
in the estimating model are purely $\mathrm{I}(0)$, purely $\mathrm{I}(1)$ ) or mutually integrated (Oteng-Abayie \& Frimpong, 2006). The test states that if F-statistics is higher than the upper bound I(1), then the variables are co-integrated. While if the F-statistics is less than the lower bound $\mathrm{I}(0)$, then the variables are not co-integrated. The result for the ARDL Co-Integrated Bound Test for this research study in Table 3 shows that the variables are co-integrated, the F-statistics is higher than the upper bound I(1) at 5\% level of significance.

Table 3. ARDL Bound Co-Integration Test

\begin{tabular}{lcc}
\hline \multicolumn{1}{c}{ Test Statistic } & Value & K \\
\hline F-statistic & 10.13983 & 4 \\
Critical Value Bounds & & \\
Significance & I(0) Bound & I(1) Bound \\
$5 \%$ & 2.86 & 4.01 \\
$1 \%$ & 3.74 & 5.06 \\
\hline
\end{tabular}

Sources: Data processing

The long-run regression estimate on the impact of foreign aid on child mortality rate presents in Table 4. The estimate shows that foreign aid (FAID) had a negative impact on the child mortality rate (CMMR) in Nigeria. Also, government expenditure on health (LGHE), economic growth (LEG), and carbon dioxide emission (CO) all had a negative impact on child mortality rate (CMR) in Nigeria. Statistically, there is a significant impact of foreign aid on child mortality rate in Nigeria, which implies that a unit increase in government spending on health expects to reduce the child mortality rate by 0.04 units in the long run. At the same time, there is a significant impact of economic growth on child mortality in Nigeria, implying that a unit increase in economic growth (LEG) expects to decrease the child mortality rate in Nigeria by 11.17 respectively in the long run.

Table 4. Long Run Estimate

\begin{tabular}{cccccc}
\hline Dependent Variable & Regressor & Coefficient & Std. Error & t-Statistic & Prob. \\
\hline CMR & C & 338.1146 & 23.9128 & 14.1395 & 0.0000 \\
& LFAID & -0.0443 & 0.0046 & -9.6673 & 0.0000 \\
& LGHE & -0.2899 & 0.0122 & -23.8380 & 0.0000 \\
& LEG & -11.1774 & 2.4462 & -4.5692 & 0.0018 \\
& CO & -29.0254 & 2.2049 & -13.1641 & 0.0000 \\
\hline
\end{tabular}

Sources: Data processing

The negative relationship between foreign aids and the child mortality rate is in line with a priori expectation and shows that aid flow to Nigeria has contributed to reducing child mortality in Nigeria. This finding is in line with Kotsadam et al. (2018) and Banchani \& Swiss (2019), but in contrast with Dingle et al. (2020), Yousuf (2012), and Johnson \& Peter (2009). Also, the adverse effects of government expenditure and economic growth on child mortality 
are in line with a priori expectation and suggest that government expenditure and economic growth have contributed to reducing the child mortality rate in Nigeria. However, the negative relationship between carbon dioxide emission and child mortality is in contrast with a priori expectation that is surprising.

The short-run regression estimate on the impact of foreign aid on child mortality rate presents in Table 5. The results from the short run regression estimate show that in the current period, government expenditure on health has a positive impact on child mortality, while the first lagged value of government expenditure on health has a negative impact on child mortality rate in the short run. In the current period, the value of carbon dioxide emission has a negative impact on the child mortality rate, while the third lagged value of carbon dioxide emission also had a negative impact on the child mortality rate in the short run. The error correction term $(\operatorname{ECM}(-1))$ from the short run regression estimate shows to be negative. The coefficient of the error correction term is -1.55 . Also, the coefficient of multiple determinations $\left(\mathrm{R}^{2}\right)$ shows that the explanatory variables explain 84.72 percent of variations in child mortality rate while factors explain the remaining 15.28 percent of variations in child mortality rate outside of the model. The Durbin-Watson Statistics of 1.98 shows that the regression estimate is relatively free from the problem of serial correlation, and that estimate is appropriate for policy reference. There is a negative relationship between foreign aid and child mortality rate because when the government gets more aid or grants if properly utilized, it expects to reduce the rate of child mortality in Nigeria.

Table 5. Short Run Coefficients

\begin{tabular}{lcccc}
\hline \multicolumn{1}{c}{ Variable } & Coefficient & Std. Error & t-Statistic & Prob. \\
\hline $\mathrm{D}(\mathrm{GHE})$ & 0.040175 & 0.012585 & 3.192232 & 0.0128 \\
$\mathrm{D}(\mathrm{GHE}(-1))$ & -0.02475 & 0.006752 & -3.6657 & 0.0063 \\
$\mathrm{D}(\mathrm{CO})$ & -3.33652 & 0.594627 & -5.61112 & 0.0005 \\
$\mathrm{D}(\mathrm{CO}(-3))$ & -1.8734 & 0.669968 & -2.79625 & 0.0233 \\
CointEq(-1) & -1.55249 & 0.090934 & -17.0727 & 0.0000 \\
\hline
\end{tabular}

R-squared $=0.847$

Adjusted R- squared $=0.800$

Durbin-Watson 1.98453

Sources: Data processing

\section{Conclusion}

The paper focused on the impact of foreign aid on child mortality rate in Nigeria using annual data from 1981 to 2018. This study showed that foreign aid and government expenditure on health has a negative relationship on the child mortality rate in the long run, while economic growth has a negative relationship with the child mortality rate. The negative relationship between foreign aids and the child mortality rate is in line with a priori expectation and shows that aid flow to Nigeria has contributed to reducing child mortality in Nigeria. 
The policy implication of these findings is that the government should ensure that all foreign aid and grants give to the country should use immediately to reduce child mortality rate by building the necessary infrastructure and making it readily available to be assessed. New policies should make to reduce carbon dioxide emissions. The increase in economic activity could lead to an increase in carbon dioxide emission and other harmful gasses, so new policies should be made to use greener and renewable sources of energy to reduce harmful gasses to the atmosphere. Good governance should ensure to guarantee that the foreign aid and government expenditure on health utilize for the specific purpose of reducing the child mortality rate by eradicating corrupt practices.

\section{References}

Alan Guttmecher Institute. (1995). Hopes and Realities: Closing the Gap between Women's Aspirations and their Reproductive Experiences. New York: AGI.

Bakare, A. S. (2011). The Macroeconomic Impact of Foreign Aid in Sub-Saharan Africa: The Case of Nigeria. Business and Management Review, 1(5), 24 - 32.

Banchani, E., \& Swiss, L. (2019). The Impact of Foreign Aid on Maternal Mortality, United Nation University UNU-WIDER. Working Paper, 2019/11.

Bashir, O. K. (2013). Foreign Assistance and Economic Growth in Nigeria: The Two-Gap Model Framework. American International Journal of Contemporary Research, 3(10), 153-160.

Clements, P. (2020). Improving Learning and Accountability in Foreign Aid. World Development, 125, 1-10. https://doi.org/10.1016/j.worlddev.2019.104670.

Dingle, A., Schäferhoff, M., Borghi, J., Sabin, M.L., Arregoces, L., Martinez-Alvarez, M., \& Pitt, C. (2020). Estimates of Aid for Reproductive, Maternal, Newborn, and Child Health: Findings from Application of the Muskoka 2 Method. The Lancet Global Health, 8(3), 374-386. https://doi.org/10.1016/S2214-109X(20)30005-X

Easterly, W. (2006). The White Man's Burden. New York. USA: Penguin.

Fasanya, I. O., \& Onakoya, A. B. (2012). Does Foreign Aid Accelerate Economic Growth? An Empirical Analysis for Nigeria. International Journal of Economics and Financial, 2(4), 423-431.

Institute for Health Metrics and Evaluation. (2018). Financing Global Health 2017: Funding Universal Health Coverage and the Unfinished HIVIAID Agenda. Seattle : Institute for Health Metrics and Evaluation.

Johnson, P. A., \& Peter, Q. (2009). Foreign Aid and the Human Development Indicators in Sub-Saharan Africa. Journal of Developing Societies, 25(1), 57-83.

Joseph, B. N., Abimiku, C. A., Dangiwa, D. A., Umar, D. M., Bulus, K. I., \& Dapar, M. L.P (2017). Foreign Aid Initiatives and the HIV/AID Epidemic in Nigeria: Perspectives on Country Ownership and Humanistic Care. International STD Research \& Reviews, 5(3), 1-14.

Klugman, J., Li, L., Barker, K.M., Parssonss, J., \& Dale, K (2019). How are the Domains of Women's Inclusion, Justice, and Security Associated with Maternal and Infant Mortality Across Countries? Insights from the Women, Peace, and Security Index. SSM-Population Health, 9, 1-10. 
Kaya, I., \& Kaya, O. (2020). Foreign Aid, Institutional Quality and Government Fiscal Behavior in Emerging Economies: An Empirical Investigation. The Quarterly Review of Economics and Finance, 76, 59-67. https://doi.org/10.1016/j.qref.2019.08.004.

Kotsadam, A., Østby, G., Rustad, S. A., Tollefsen, A. F., \& Urdal, H. (2018). Development Aid and Infant Mortality. Micro-level Evidence from Nigeria. World Development, 105, 5969. https://doi.org/10.1016/j.worlddev.2017.12.022.

Maruta, A. A., Benerjee, R., \& Cavoli, T. (2020). Foreign Aid, Institutional Quality and Economic Growth: Evidence from the Developing World. Economic Modeling, 89, 444463. https://doi.org/10.1016/j.econmod.2019.11.008

Masud, N., \& Yontcheva, B. (2005). Does Foreign Aid Reduce Poverty? Empirical Evidence from Non-Governmental and Bilateral Aid. IMF Working Paper, 5(100), 145-156.

Mishra, P., \& Newhouse, D. (2009). Does Health Aid Matter?. Journal of Health Economics, 28(4), 855-872. https://doi.org/10.1016/j.jhealeco.2009.05.004.

Moyo, D. (2009). Dead Aid: Why Aid is Not Working and How There is a Better Way for Africa. New York: Farrar, Straus and Giroux.

Nasim, S. S., Turkhan, A. A., \& Muhammad, A. (2009). Effectiveness of Foreign Aid and Human Development. Pakistan Development Review, 48(4), 853-862.

Olabode, A., \& Salam, S. M. (2018). Impact of Foreign Aid on the Economic Development of Nigeria: 1986-2016. Journal of Economic and Sustainable Development, 9(18), 69-80.

Oteng-Abayie, E., \& Frimpong J. (2006). Bounds Testing Approach to Co-integration: An Examination of Foreign Direct Investment, Trade and Growth Relationships. American Journal of Applied Sciences, 3(11), 2079-2085.

Pandolfelli, L. E., Shandra, J., \& Tyagi, J. (2014). The International Monetary Fund, Structural Adjustment, and Women's Health: A Cross-National Analysis of Maternal Mortality in Sub-Saharan Africa. The Sociological Quarterly, 55(1), 119-142. https://doi.org/10.1111/ tsq. 12046 .

Proulx, K. R., Ruckert, A., \& Labonté, R. (2017). Canada’s Flagship Development Priority: Maternal, Newborn and Child Health $(\mathrm{MNCH})$ and the Sustainable Development Goals (SDGs). Canadian Journal of Development Studies, 38(1), 39-53.

Staicu, G., \& Barbulescu, R. (2017). A Study of the Relationship between Foreign Aid and Human Development in Africa. IntechOpen, 135-152.

Thomson, M., Kentikelenis, A., \& Stubbs, T. (2017). Structural Adjustment Programmes Adversely Affect Vulnerable Populations: A Systematic-Narrative Review of their Effect on Child and Maternal Health. Public Health Reviews, 38(13), 1-18. https://doi. org/10.1186/s40985-017-0059-2

Winters, M. S. (2010). Accountability, Participation and Foreign Aid Effectiveness. International Studies Review, 12(2), 218-243.

Yogo, U. T., \& Mallaye, D. (2015). Health Aid and Health Improvement in Sub-Saharan Africa: Accounting for the Heterogeneity between Stable States and Post-Conflict States. Journal of International Development, 27(7), 1178-1196. https://doi.org/10.1002/ jid.3034.

Yousuf, A. S. (2012). Impact of Health Aid on Infant Mortality Rate. Munich Personal RePEc Archive (MPRA), Paper No. 42945. https://mpra.ub.unimucnchon.de/42945/ 